\title{
Related but not alike: not all Hemiptera are attracted to yellow
}

\author{
Kevin Farnier $^{1 *}$, Adrian G. Dyer ${ }^{2}$ and Martin J. Steinbauer ${ }^{1}$ \\ ${ }^{1}$ Insect-Plant Interactions Lab, Department of Zoology, La Trobe University, Melbourne, VIC, Australia \\ ${ }^{2}$ School of Media and Communication, RMIT University, Melbourne, VIC, Australia
}

\section{Edited by:}

Martin Stevens, University of

Exeter, UK

Reviewed by:

Anna Balkenius, Swedish University

of Agricultural Science, Sweden

Thomas Felix Döring, Humboldt

University Berlin, Germany

Klaus Lunau,

Heonrich-Heine-University

Duesseldorf, Germany

*Correspondence:

Kevin Farnier, Department of

Zoology, La Trobe University,

Kingsbury Drive, Melbourne, VIC

3086, Australia

e-mail:kfarnier@

students.latrobe.edu.au
Most innate responses to color stimuli lead herbivorous insects to orient to "green" and "yellow" surfaces. Early research showed that aphid orientation to plants is influenced by foliar pigments and leads them to alight on leaves of a specific physiological state regardless of whether or not it is their actual host. In this study, we quantified the color preferences of four psyllids specialized on young to recently expanded leaves of different Eucalyptus hosts presenting distinct between (inter-specific) and within canopy (ontogenic) optical characteristics. Color preferences of Ctenarytaina eucalypti and C. bipartita were similar to those observed in aphids with more frequent selection of yellow and green stimuli, consistent with the coloration of their host leaves. However, attraction of Anoeconeossa bundoorensis and Glycaspis brimblecombei to a red stimulus contrasts strongly with the literature for hemipteran and herbivorous insects generally for which attraction to red is peculiar. Interestingly, both red-attracted species occur on the same host eucalypt, which expresses anthocyanic (red) young leaves. Our experiments demonstrate that these two species are sensitive to long wavelength radiation. Behavioral responses and modeling of putative "aphid-like" photoreceptors were conducted to investigate whether achromatic vision mediates perception of "red." Our results do not provide strong evidence for an intensity-dependant type of attraction. Nevertheless, the current knowledge of photoreceptors in Hemiptera identifies the achromatic pathway as the most likely mechanism for detecting long wavelengths. Thus, our findings highlight the need for physiological work with Psylloidae to elucidate the mechanisms responsible for such atypical responses. We discuss the ecological implications of our work in relation to red foliar pigments in expanding leaves of perennial plants which differs greatly from the thoroughly studied aphid-autumnal leaves system involving senescing foliage.

\section{Keywords: plant pigments, color vision, anthocyanins, host selection}

\section{INTRODUCTION}

Hemiptera is an ancient insect order (Permian) widely represented with nearly 100,000 species described in 145 families (Grimaldi, 2005; Gullan and Cranston, 2009). With the exception of a few predators and scavengers, Hemiptera are dominantly phytophagous ( $\approx 90 \%$ of species) and feed on a wide array of angiosperms and a few gymnosperms. They possess characteristic sucking mouthparts that they use to pierce plant tissues to access their feeding site (i.e., phloem, xylem or parenchyma) and a filtering chamber allowing them to extract liquid content (Carver et al., 1991). Psyllids (Psylloidea) belong to the monophyletic suborder Sternorrhyncha, a sister group of the rest of the Hemiptera, which includes aphids, whiteflies and scale insects. There are about 3000 species of psyllid worldwide (Hodkinson, 2009) of which approximately 350 are native to Australia (Hollis, 2004). The superfamily Psylloidea, which is more abundant and diverse in Australasia than in the northern hemisphere, is largely composed of acacia and eucalypt-feeding species, with the latter arguably having the closest associations with their host plants (Carver et al., 1991; Hollis, 2004; Hodkinson,
2009). Currently, the mechanisms psyllids employ to locate their host in complex mixed-vegetation habitats remain poorly understood.

Host selection by herbivorous insects revolves around successive steps starting from random foraging to location, recognition, assessment, and eventually acceptance or rejection of a plant as host for feeding and/or oviposition. All steps involve different senses and occur at varying distances from the plant surface. Since olfactory and visual cues are perceptible at distance, they play a determinant role in plant location by foraging insects (Schoonhoven et al., 1998). Plants produce a wide array of volatile compounds, which differ greatly in quality and quantity between species. These air-borne chemical "signatures" and their spatiotemporal variations offer a great variety of unique and specific cues that insects have evolved to recognize during their association with their host(s) (Visser, 1986; Bernays, 1998). In contrast, the diversity of visual cues reflected by plants is limited by the narrower variety of foliar pigments, which cause them to vary essentially in the "green-yellow-orange" part of the light spectrum visible to insects. As a result, olfaction is considered to provide 
more characteristic and reliable cues to insects in search of a specific host (Prokopy and Owens, 1983; Döring, 2014).

Nevertheless, most research indicates that vision is essential in aphid and whitefly orientation and most early studies failed to observe any chemotactic responses to host plant volatiles (Kennedy and Stroyan, 1959; Kennedy et al., 1961; Vaishampayan et al., 1975b; Pickett et al., 1992). More recent works have revealed behavioral and electrophysiological responses to host plant volatiles (Pickett et al., 1992; Visser et al., 1996; Pickett and Glinwood, 2007), which presumably assist host-alternating aphids during their migration and return to seasonal hosts. Similar observations were made with whiteflies (Vaishampayan et al., 1975b; Mellor and Anderson, 1995; Bleeker et al., 2009) although, as in aphids, the simultaneous application of visual stimuli was often required to elicit chemotactic responses to host plant odors.

One reason why many Sternorrhyncha rely to a lesser extent on olfaction probably resides in their poor abilities of active flight, which greatly hinders their capacity to follow airborne signals. Studies of flight behavior have shown that aphids and whiteflies use vision to control their groundspeed but can't sustain upwind flights in airflows exceeding $1 \mathrm{~m} . \mathrm{s}^{-1}$ (Kennedy and Stroyan, 1959; Kennedy and Thomas, 1974; Isaacs et al., 1999). Thus, their flight abilities are restricted in terms of distance (i.e., a few meters) and altitude. Migrations over long distances, observed during host alternation, are principally wind-assisted.

Visual perception of color stimuli has been shown to strongly influence aphids and whiteflies orientation. Most studies have shown that aphids (Kennedy et al., 1961; Moericke, 1969; Prokopy and Owens, 1983; Hardie, 1989; Döring, 2014) and whiteflies (Vaishampayan et al., 1975a,b; Coombe, 1982; Isaacs et al., 1999) orient preferentially toward green and yellow surfaces. Insect color perception is dependent upon the sensitivity of their photoreceptors. Since most insects possess the same chromophore (vitamin A1 based, 11-cis retinal), their sensitivity to light wavelength remains relatively conserved exhibiting maximal sensitivities in the UV, blue and green regions of the light spectrum (Briscoe and Chittka, 2001). Although it has not been as clearly demonstrated as with honeybees using psychophysics and electrophysiology (von Frisch, 1914; Daumer, 1956; Von Helversen, 1972; Peitsch et al., 1992), early studies demonstrated that aphids do exhibit intensity-independent behaviors in response to specific wavelengths (Moericke, 1955b) and are likely to possess a color-opponent mechanism (Moericke, 1950; Chittka and Döring, 2007) which are prerequisites for color vision (Menzel, 1979; Kelber et al., 2003). Moreover, recent works involving electrophysiological techniques have confirmed the existence of three photoreceptor types in at least two species of aphids (Kirchner et al., 2005; Döring et al., 2011). As a consequence, although it has not been convincingly demonstrated, aphids are suspected to have color vision (Döring and Chittka, 2007).

Unlike aphids and whiteflies, color preferences in psyllids have rarely been tested. This is mostly due to the fact that psyllids, like aphids, are presumed to be responsive to yellow-green (Mensah and Madden, 1992; Brennan and Weinbaum, 2001; Al-Jabr and Cranshaw, 2007; Hall et al., 2010), and therefore research has concentrated more on their olfactory responses (Valterovà et al., 1997; Soroker et al., 2004; Gross and Mekonen, 2005; Mayer et al., 2008; Patt and Sétamou, 2010). However, as in aphids, psyllids exhibit only weak chemotactic responses in the absence of visual cues (Hodkinson, 1974; Wenninger et al., 2009; Patt et al., 2011) and seem to possess an even less developed olfactory apparatuswhich may only operate in host alternating species. An obvious limiting factor in the understanding of visual mechanisms in psyllids in psyllids is small size and the softness of their eyes, which has impeded the acquisition of physiological data.

In this study, we quantified the color preferences of four species of psyllid specialized on young to recently expanded leaves of different eucalypt hosts displaying distinct inter- and intra-specific optical characteristics. We sought to address the following topics: (1) whether psyllid color preferences are comparable to those exhibited by aphids and whiteflies; (2) whether color preferences are conserved between species; (3) whether the attraction to long wavelengths (red) exhibited by two of the species relies on stimuli intensity and/or their contrast against the background. Our ultimate objective, of which this study is an initial component, is to determine the ecological significance of vision in the utilization of eucalypts by psyllids. Red coloration of young leaves is not uncommon in eucalypts, which suggests that attraction to long wavelengths may occur in many other eucalypt-feeding psyllids.

\section{MATERIALS AND METHODS PSYLLIDS}

Psyllids were field collected within the State of Victoria (Australia) and colonies of each species maintained in a climate-controlled glasshouse on potted hosts of Eucalyptus globulus (C. eucalypti), E. kitsoniana (C. bipartita), and E. camaldulensis (A. bundoorensis and $G$. brimblecombei). Since psyllids were most abundant during the austral spring-summer, most bioassays were conducted between November and April when the most characteristic host location and assessment behaviors are exhibited in the field.

\section{BEHAVIORAL BIOASSAY}

Preliminary studies to devise an effective bioassay to study psyllid color preferences began in April 2011. Color preferences were assessed in a multiple-choice arena (described in Figure 1). The arena was formed using a $15.5 \mathrm{~cm}$ diameter glass Petri dish, the inside of which was lined with a gray non-fluorescent background cardboard (160 gsm; K.W Doggett, Melbourne, Australia) with the same underneath. Background and stimuli colors were edited using Microsoft Powerpoint using custom RGB settings and printed on the same cardboard sheets (to avoid the use of glue) using a Xerox 4350 printer. The gray background color was identical in all experiments (R:166, G:166, B:166; 35\% light reflecting). Stimuli were square color targets $(4 \times 4 \mathrm{~cm})$ presented on the "walls" equidistantly distributed around the perimeter of the arena. Males and females were tested in separate arenas and the surface of the dish was wiped with $90 \%$ ethanol after every second or third insect to eliminate any potential influence from olfactory cues. Arenas were rotated $90^{\circ}$ after every psyllid to exclude potential position effects. Stimuli and their spatial order were replaced several times a day (after every 12 insects at most) and a new arena used after each series of bioassays. 


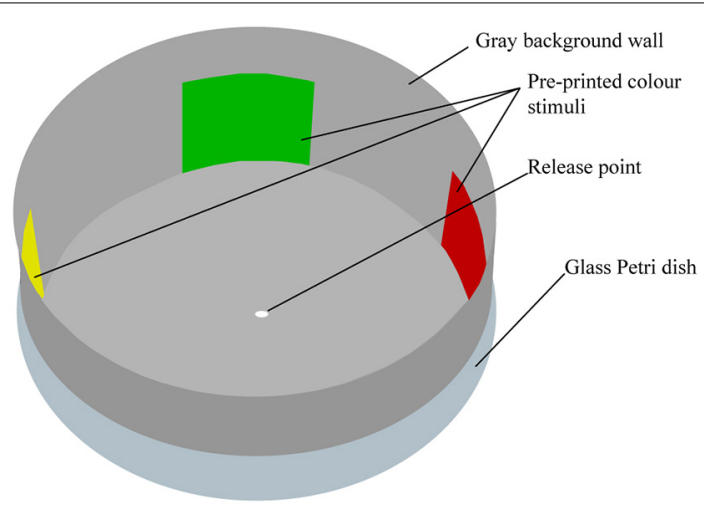

FIGURE 1 | Illustration of the color choice bioassay. Psyllids were placed initially on the white dot in the center of the arena and allowed $30 \mathrm{~min}$ to choose one of the vertical color targets. A choice is considered to have been made when the psyllid adopts a vertical position on any area of the wall of the arena.

Tests were conducted in a controlled laboratory chamber surrounded by white fabric curtains and illuminated from the top by four Philips Master TLS HE slimline $28 \mathrm{~W} / 865 \mathrm{UV}+$ daylight fluorescent tubes (Philips, Holland) with specially fitted high frequency $(1200 \mathrm{~Hz})$ ATEC Jupiter EGF PMD2614-35 electronic dimmable ballasts. A sheet of Rosco 216 white diffusion screen (Rosco, Munich, Germany), which does not impede UV transmission, was used to diffuse the light in the chamber, providing a controlled illumination close to the spectral quality of natural illumination for insects (Dyer, 2006). The intensity of light in the arena was measured with a Fieldscout Quantum light meter (Spectrum Technologies, Inc., USA) and kept constant at $70 \mu \mathrm{mol} \cdot \mathrm{m}^{-2} \cdot \mathrm{s}^{-1}(\approx 5180 \mathrm{lux})$. The illumination under the screen to which psyllids were exposed is shown in Figure 2A.

Innate color preference of psyllids from glasshouse colonies was tested individually and only once to eliminate pseudoreplication effects. Each insect was cooled in a freezer for up to $240 \mathrm{~s}$ to be anaesthetized before being placed in the center of the arena with a fine paintbrush. A video camera (540TVL high resolution, EVO series, Pacific Communications, Australia) was positioned approximately $60 \mathrm{~cm}$ above the arena allowing real time observation of psyllid behavior. After approximately $2 \mathrm{~min}$, psyllids recovered and began foraging. Each psyllid was allowed to roam the arena for up to $30 \mathrm{~min}$. Whilst this required a long test time to collect data, the method enables a unique perspective on how psyllids make color choices. Psyllid foraging behavior and their trajectories varied markedly between species. However, all insects were apparently able to perceive color stimuli from across the dish and most individuals tested exhibited a number of turns in the central area of the arena before orientating directly toward one of the color stimuli. A choice was considered to have been made when a psyllid climbed the wall of the arena. The color of the vertical surface on which psyllids climbed determined their choice. Psyllids climbing on the background instead of a color target were categorized as choosing "G166." In most cases, psyllids climbed on the central area of color stimuli, although a number of
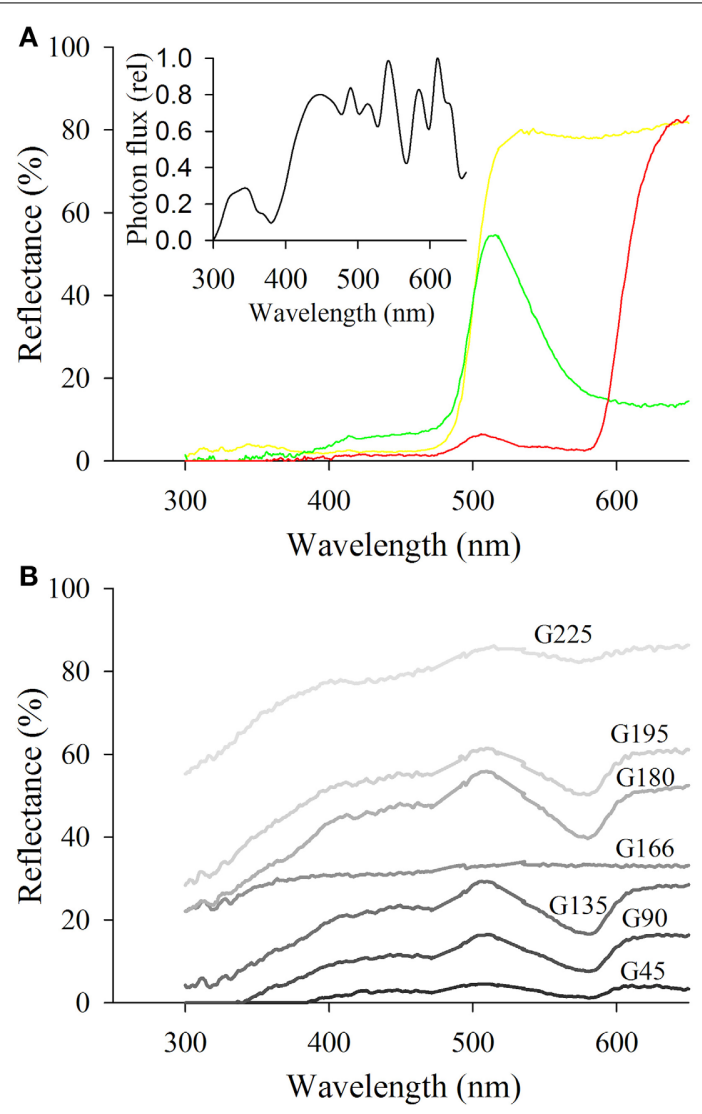

FIGURE 2 | Reflectance spectra of the different targets used as stimuli. (A) Shows targets corresponding to the green, yellow, and red targets used to assess preferences of psyllids for chromatic stimuli. The insert represents the irradiance spectrum of the lighting in the arena. (B) Represents the spectra of the different shades of gray employed to determine psyllids' attraction to achromatic stimuli. Note the spectrum of G166 corresponding to the gray used as the background color in all bioassays.

individuals chose the edge of the color square. Psyllids not having made a choice within $30 \mathrm{~min}$ were considered "non-choosing" and were not included in the data.

\section{EXPERIMENT 1: COLOR PREFERENCES}

Psyllid preferences for three color stimuli were tested first: to "green" (R:0, G:255, B:0), "yellow" (R:255, G:255, B:0), and "red" (R:255, G:0, B:0) with an equidistantly spaced gray space (reflectance spectra presented in Figure 2A). We standardized preferences for the proportion of the circumference of the arena colored by each target. Specifically, the perimeter of the background was seven-fold higher than that of each single color stimulus and consequently the probability that a psyllid would choose gray over the other available stimuli was seven times more likely if their preference was random.

\section{EXPERIMENT 2: PERCEPTION OF LONG WAVELENGTHS}

Under the assumption that the psyllid visual system is not sensitive to long wavelengths, long wavelength reflecting stimuli like "red" should be cryptic to psyllids. Therefore, we tested whether 
the two red attracted species A. bundoorensis and G. brimblecombei were able to discriminate between red and a very low reflecting stimulus, namely G45 (reflectance spectrum in Figure 2B). In this experiment, the proportion of the perimeter of the arena covered by the background was eight-fold greater than that of the red and G45 stimuli.

\section{EXPERIMENT 3: ATTRACTION AS AFFECTED BY STIMULUS INTENSITY}

To test whether the choice of the two species A. bundoorensis and G. brimblecombei attracted to the red is influenced by stimulus intensity, their preferences for six shades of gray stimuli $(4 \times 4 \mathrm{~cm})$ presenting a relatively similar and constant reflectance across the spectrum but with different intensities was tested (reflectance spectra in Figure 2B). Under these conditions, if psyllid attraction to "red" was intensity-dependent, we would expect psyllids to preferentially choose a particular (achromatic) gray stimulus. The proportion of the perimeter of the arena occupied by the background was four-fold greater than that of the other gray stimuli.

\section{REFLECTANCE MEASUREMENTS}

Reflectance spectra between 300 and $800 \mathrm{~nm}$ were measured with a USB200+ UV-Vis miniature Fiber Optic spectrometer (Ocean Optics) equipped with a pulsed xenon module and a $400 \mu \mathrm{m}$ reflection probe. A freshly pressed pellet of dry $\mathrm{BaSO} 4$ was used as a white standard (including UV reflectance) to calibrate the spectrophotometer.

\section{CALCULATION OF STIMULI INTENSITY CONTRAST}

In the absence of color vision, insects can rely on receptor specific contrast or brightness to locate objects in their environment. We tested how psyllid choice was influenced by the physical intensity (contrast) of the stimuli against the background. We calculated the intensity contrast of the different stimuli used in the arena against the gray background as described in Koshitaka et al. (2011). We first calculated the intensity of different stimuli using Equation (1):

$$
I_{s}=\int_{300}^{650} R_{s}(\lambda) \mathrm{L}(\lambda) \mathrm{d} \lambda / \int_{300}^{650} \mathrm{~L}(\lambda) \mathrm{d} \lambda
$$

Where $I_{s}$ is the intensity of the stimulus, $R_{s}(\lambda)$ the reflectance and $L(\lambda)$ the illumination spectrum.

Then, we calculated the contrast using Equation (2):

$$
I C=\log _{10} \frac{I_{s}}{I_{b}}
$$

Where IC is the intensity contrast, $I_{s}$ the intensity of the stimulus and $I_{b}$ the intensity of the background.

Finally, we compared psyllid choices with the intensity contrasts of the stimuli they were exposed to in all three behavioral experiments.

\section{ESTIMATION OF THE QUANTITY OF LIGHT ABSORBED BY RECEPTORS IN PRESENCE OF VISUAL STIMULI}

To determine how the stimuli used in our bioassays would translate in terms of excitation of a UV-blue-green set of receptors under our experimental conditions, we assessed the photon catch of putative psyllid photoreceptors. These calculations aim to indicate whether a visual system comparable to that described for other Sternorrhyncha (e.g., aphids) could explain the results obtained in our behavioral bioassays. The quantity of light absorbed was calculated using Equation (3):

$$
P R=\int_{300}^{650} R_{s}(\lambda) S_{r}(\lambda) \mathrm{L}(\lambda) \mathrm{d} \lambda / \int_{300}^{650} R_{b}(\lambda) S_{r}(\lambda) \mathrm{L}(\lambda) \mathrm{d} \lambda
$$

Where $P R$ is the light absorbed, $R_{S}(\lambda)$ the reflectance spectrum of the stimulus, $S_{r}(\lambda)$ the sensitivity of the photoreceptors, $L(\lambda)$ the irradiance of the light source and $R_{b}(\lambda)$ the reflectance spectrum of the background. Since the sensitivity of psyllid photoreceptors is currently not known, we used a Stavenga template for chromophore A1, the most commonly encountered chromophore in insects, to model spectral sensitivities (Stavenga et al., 1993). By default, we set the maxima of the hypothetical spectral sensitivities at $340 \mathrm{~nm}$ for the $\beta$ band and varied the $\lambda_{\max }$ of the $\alpha$ band; from 330 up to $360 \mathrm{~nm}$ at $10 \mathrm{~nm}$ step intervals for the UV receptor, $430 \mathrm{up}$ to $460 \mathrm{~nm}$ for the blue receptor and $530-560 \mathrm{~nm}$ for the green receptor based on plausible data from Briscoe and Chittka (2001). The putative photosensitivities used to calculate photoreceptor stimulations are represented in Figure 3. We considered the photon catch for each value of the $\alpha$ band of each hypothetical photoreceptor and calculated so the relative absorbed light in presence of visual stimuli employed in our experiments against G166 used as background.

\section{STATISTICAL ANALYSES}

The influence of gender on color preference was tested using nominal logistic regression (Quinn and Keough, 2002). For none

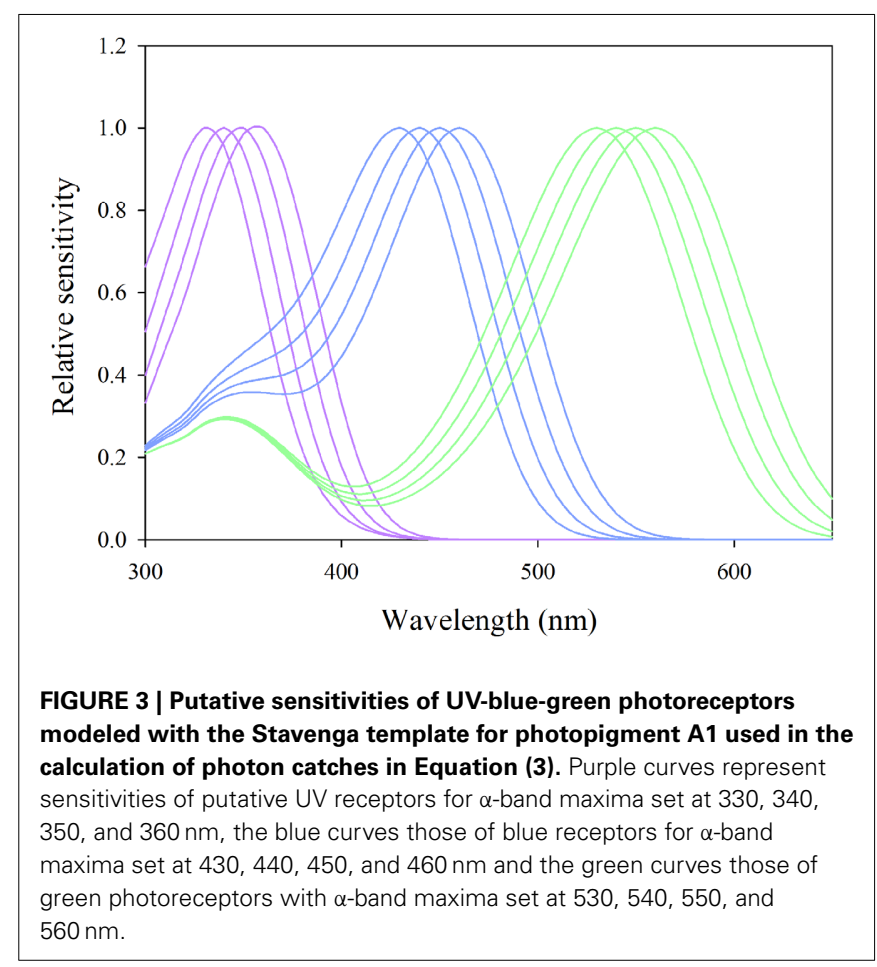


of the species tested was gender a significant influence on their color preference: C. eucalypti $\mathrm{G}(3, n=127)=4.443, p=0.27$; C. bipartita $\mathrm{G}(3, n=125)=1.174, p=0.759 ;$ A. bundoorensis $\mathrm{G}(3, n=92)=0.653, p=0.884 ;$ G. brimblecombei $\mathrm{G}(3$, $n=104)=7.101, p=0.137$. Consequently, color preference data for males and females were pooled. Color preference data were analyzed using $G$-tests with sequential Bonferroni correction for multiple comparisons. Position effects were checked using Chi-square tests.

\section{RESULTS}

EXPERIMENT 1: COLOR STIMULI PREFERENCES OF DIFFERENT PSYLLID SPECIES

Ctenarytaina eucalypti demonstrated a statistically significant preference for green over red while attraction to yellow did not differ significantly from that of green and red (Figure 4A). Ctenarytaina bipartita exhibited somewhat similar color preferences to C. eucalypti (Figure 4B), however this species was equally attracted to yellow and green and significantly less attracted to red. Anoeconeossa bundoorensis was more attracted to red than the other color stimuli and yellow attracted significantly more individuals than green (Figure 4C). Glycaspis brimblecombei responded in a similar manner as A. bundoorensis (Figure 4D). In all four species, individual psyllids only infrequently chose the background (Table $\mathbf{1}$ ).

\section{EXPERIMENT 2: RED vs. DARK GRAY (G45)}

Anoeconeossa bundoorensis and G. brimblecombei exhibited strong preferences when exposed to achromatic (G45) and chromatic (red) stimuli (Figures 5A,B); both species were attracted to the red stimulus (Table 2 ).

\section{EXPERIMENT 3: ORIENTATION TOWARD ACHROMATIC STIMULI}

Anoeconeossa bundoorensis and G. brimblecombei exhibited preference for specific shades of gray (Figures 6A,B). Anoeconeossa bundoorensis preferred the darkest target $(\mathrm{G} 45)$ to the others. The brightest gray stimulus (G225) was the second most attractive while G135 was the least attractive gray. A similar result was observed with $G$. brimblecombei. However, no significant attraction to a specific gray was observed (Table 2). The apparent bimodal distribution of psyllid choices for the different gray stimuli observed with $A$. bundoorensis, and to a much lesser extent with $G$. brimblecombei, suggests that the capacity to detect stimuli against the gray background may have been the main factor influencing their responses, i.e., psyllids exhibited a tendency to choose stimuli that were darker or brighter than the background gray.

\section{INFLUENCE OF STIMULI INTENSITY CONTRAST ON PSYLLID CHOICE}

Yellow had the highest intensity ahead of green and red, respectively. It was also the only stimulus used in Experiment
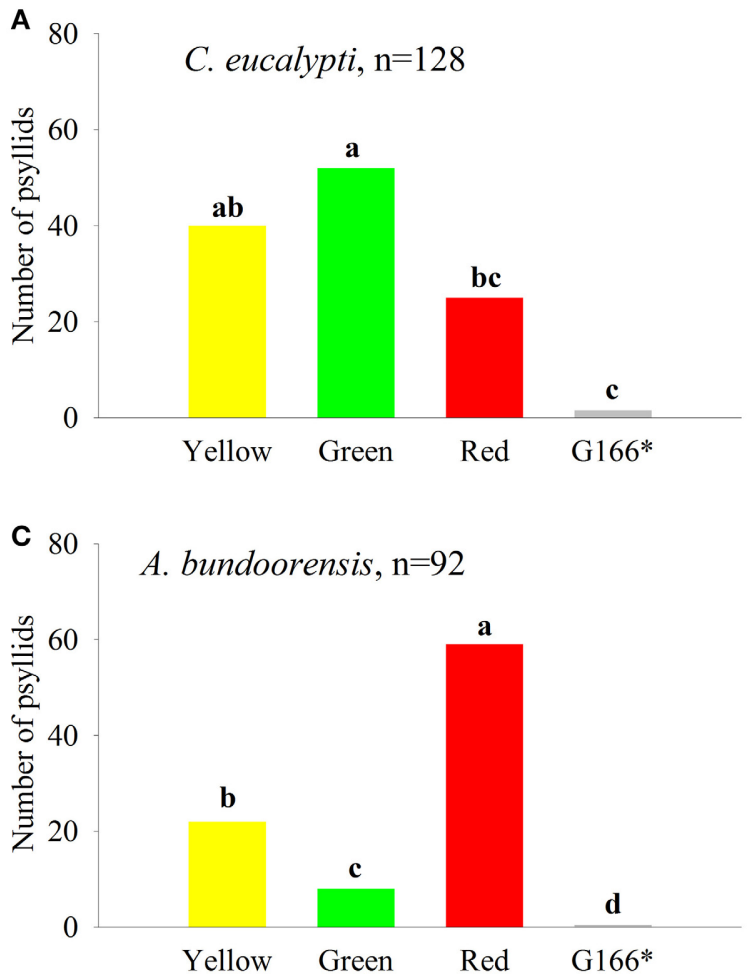

FIGURE 4 | Psyllid responses to color stimuli. (A) C. eucalypti,

(B) C. bipartita, (C) A. bundoorensis and (D) G. brimblecombei. $\mathrm{n}$ represents the sample size for each species. Letters above the bars, group color stimuli
B

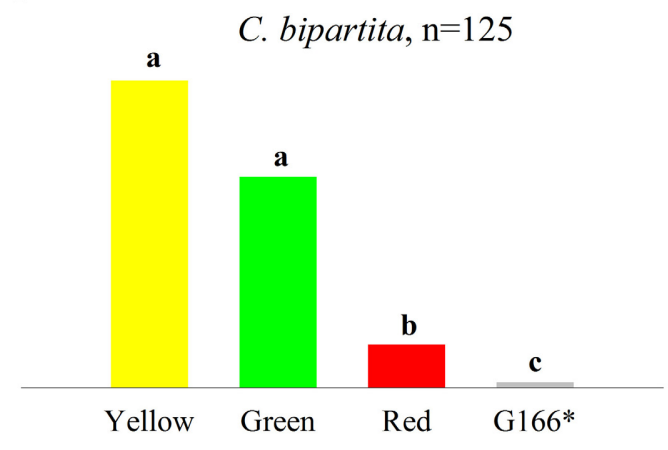

D

G. brimblecombei, $\mathrm{n}=104$

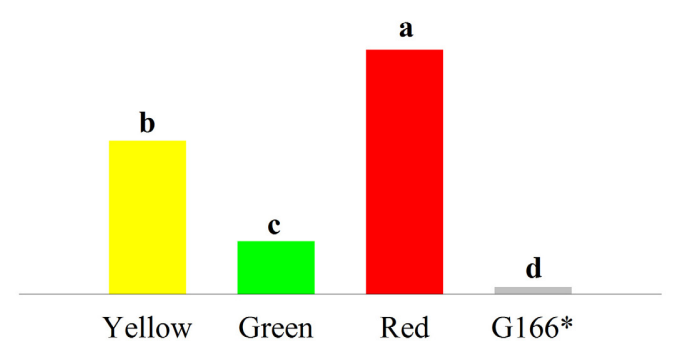

by level of statistical significance. *Number of psyllids was normalized based upon the proportion of the circumference occupied by the background color in the arena. 
Table 1 | Summary of statistical tests of bioassays with colored stimuli (Experiment 1).

\begin{tabular}{|c|c|c|c|c|}
\hline & C. bipartita & C. eucalypti & A. bundoorensis & G. brimblecombei \\
\hline \multicolumn{5}{|c|}{ COLOR PREFERENCE EXPERIMENTS } \\
\hline G-test & $\mathrm{G}_{(124,3)}^{2}=105.2, p<0.001$ & $\mathrm{G}_{(128,3)}^{2}=64.67, p<0.001$ & $\mathrm{G}_{(91,3)}^{2}=94, p<0.001$ & $\mathrm{G}_{(103,3)}^{2}=71.2, p<0.001$ \\
\hline Green vs. Yellow & ns & ns & $p<0.01$ & $p<0.01$ \\
\hline vs. Red & $p<0.001$ & $p<0.01$ & $p<0.001$ & $p<0.001$ \\
\hline vs. Red & $p<0.001$ & ns & $p<0.001$ & $p<0.05$ \\
\hline Red vs. G166 & $p<0.05$ & $p=0.054$ & $p<0.001$ & $p<0.001$ \\
\hline
\end{tabular}

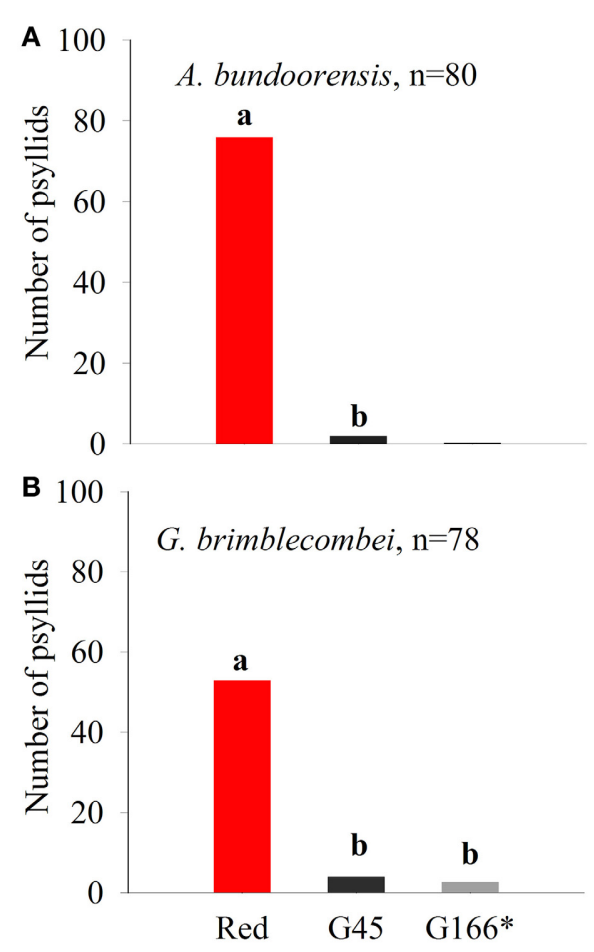

FIGURE 5 | Psyllid responses in dual choice, red vs. dark gray (G45) of (A) A. bundoorensis and (B) G. brimblecombei. *Number of psyllids was normalized based upon the proportion of the circumference occupied by the background color in the arena.

1 with an overall reflectance greater than that of the background G166. However, for none of the four species of psyllids did stimuli intensities influence their choices (Figure 7A).

Intensity contrast appears to be the main factor influencing the choice of the two red attracted species in Experiment 3 (Figures 7A,B). Both these species chose the stimuli with the highest positive or negative contrast to the background (i.e., G45 and G225). Hence, the bimodal response observed in Experiment 3 is likely to be the expression of psyllid utilization of the contrast in intensity of the stimulus compared to the background. However, intensity contrast did not appear
Table 2 | Summary of statistics for Experiment 2 (red vs. G45) and Experiment 3 (shades of gray).

\section{A. bundoorensis \\ G. brimblecombei}

\begin{tabular}{|c|c|c|}
\hline \multicolumn{3}{|c|}{ RED vs. DARK GRAY G45 } \\
\hline G-test & $\mathrm{G}_{(79,2)}^{2}=150, p<0.001$ & $\mathrm{G}_{(77,2)}^{2}=80.5, p<0.001$ \\
\hline \multicolumn{3}{|c|}{ BONFERRONI POST-HOC TEST } \\
\hline Red vs. G45 & $p<0.001$ & $p<0.001$ \\
\hline vs. G166 & $p<0.001$ & $p<0.001$ \\
\hline G45 vs. G166 & ns & ns \\
\hline
\end{tabular}

SHADES OF GRAY
G-test $\quad \mathrm{G}_{(113,6)}^{2}=71.4, p<0.001 \quad \mathrm{G}_{(115,6)}^{2}=17.0, p<0.01$

\section{BONFERRONI POST-HOC TEST}

$\begin{array}{rcc}\text { G45 vs. G90 } & p<0.001 & \mathrm{~ns} \\ \text { vs. G135 } & p<0.001 & p<0.05 \\ \text { vs. G166 } & p<0.001 & \mathrm{~ns} \\ \text { vs. G180 } & p<0.001 & \mathrm{~ns} \\ \text { vs. G195 } & p<0.001 & \mathrm{~ns} \\ \text { vs. G225 } & p<0.05 & \mathrm{~ns} \\ \mathrm{G} 90 \text { vs. G135 } & p<0.001 & \mathrm{~ns} \\ \text { vs. G166 } & \mathrm{ns} & \mathrm{ns} \\ \text { vs. G180 } & \mathrm{ns} & \mathrm{ns} \\ \text { vs. G195 } & \mathrm{ns} & \mathrm{ns} \\ \text { vs. G225 } & \mathrm{ns} & \mathrm{ns} \\ \mathrm{G} 135 \text { vs. G166 } & \mathrm{ns} & \mathrm{ns} \\ \text { vs. G180 } & p<0.05 & \mathrm{~ns} \\ \text { vs. G195 } & \mathrm{ns} & \mathrm{ns} \\ \text { vs. G225 } & p<0.001 & p<0.05 \\ \mathrm{G} 166 \text { vs. G180 } & \mathrm{ns} & \mathrm{ns} \\ \text { vs. G195 } & \mathrm{ns} & \mathrm{ns} \\ \text { vs. G225 } & p<0.05 & \mathrm{~ns} \\ \mathrm{G} 180 \text { vs. G195 } & \mathrm{ns} & \mathrm{ns} \\ \text { vs. G225 } & \mathrm{ns} & \mathrm{ns} \\ \mathrm{G} 195 \text { vs. G225 } & p<0.05 & \mathrm{~ns}\end{array}$

to be the major driver of psyllid choices in Experiments 1 and 2 (Figures 7A,B). In Experiment 1, psyllids significantly more often chose the yellow over the green stimulus despite the higher intensity contrast of the green. Likewise, in Experiment 2, psyllids preferred the red to the dark gray (G45) stimulus despite the much higher achromatic contrast presented by the latter. 


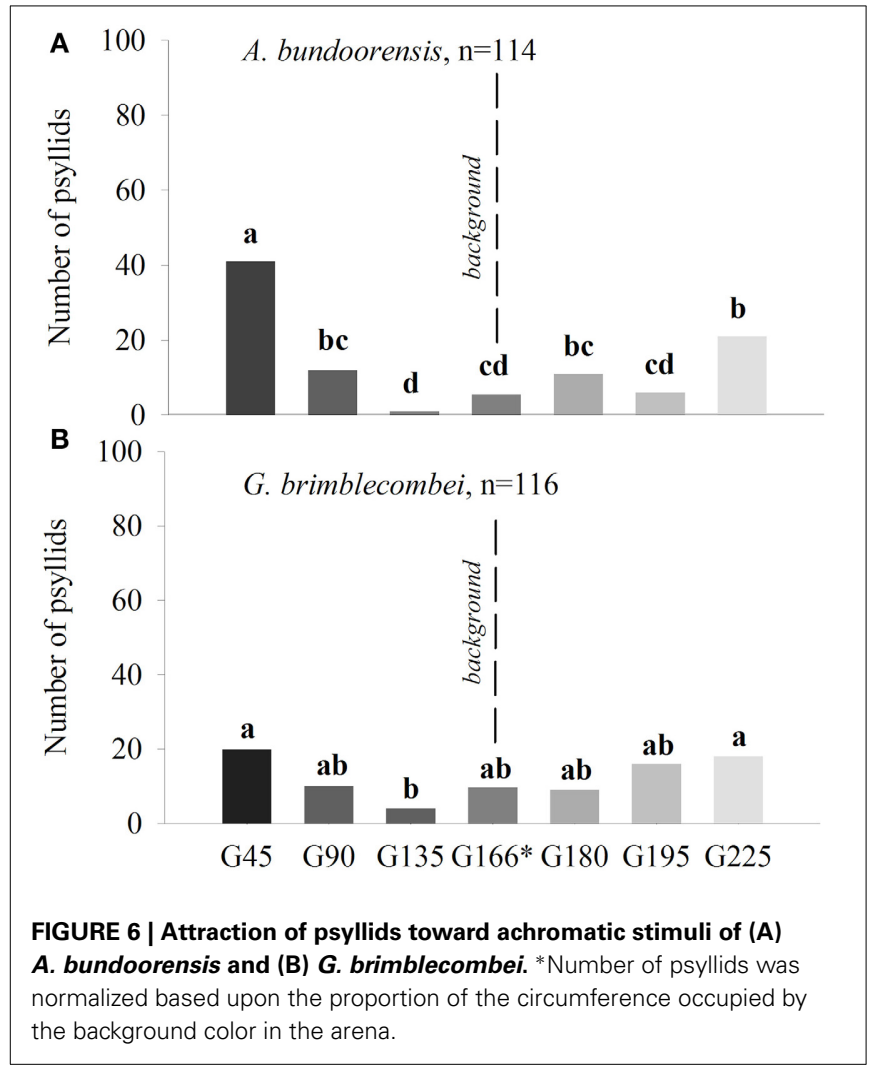

\section{LIGHT ABSORBED BY PHOTORECEPTORS MODELED USING THE STAVENGA TEMPLATE}

For all $\alpha$ band maxima of hypothetical green receptors, the photon catch of "yellow" was at least two-fold greater than that of "green" and six- to 10-fold greater than that of "red" (Figures 8A-C). The photon catch of the modeled UV and blue receptors was comparable for the "yellow" and "green stimuli" for all $\alpha$ band maxima whereas the "red" stimulus did not reflect in this region of the spectrum. The photon catch of the "red" stimulus was between that of G45 and G90 when the $\alpha$ band peaked between 530 and $550 \mathrm{~nm}$ and closely matches that of G90 for $560 \mathrm{~nm}$ (Figures 8C,F,I). The intensity of "yellow" was between that of G180 and G195 for an $\alpha$ band set at $530 \mathrm{~nm}$ and approaching the intensity of G195 for an $\alpha$ band maximum set at $560 \mathrm{~nm}$.

\section{DISCUSSION}

This study is, to our knowledge, the first to comprehensively address psyllid responses to colors under controlled conditions and using stimuli of known reflectance. Ctenarytaina eucalypti and C. bipartita were attracted to "green" and "yellow" stimuli. Ctenarytaina bipartita preferred yellow and green significantly more than red but only green was significantly more attractive to C. eucalypti than red. The preference for yellow and green stimuli exhibited by these two species concurs with the responses of other Sterrnorhyncha such as aphids (Kennedy et al., 1961) and whiteflies (Vaishampayan et al., 1975b; Coombe, 1982). Moreover, similar species-specific differences in color preferences have been shown to occur in aphids (Moericke, 1969; A'brook,
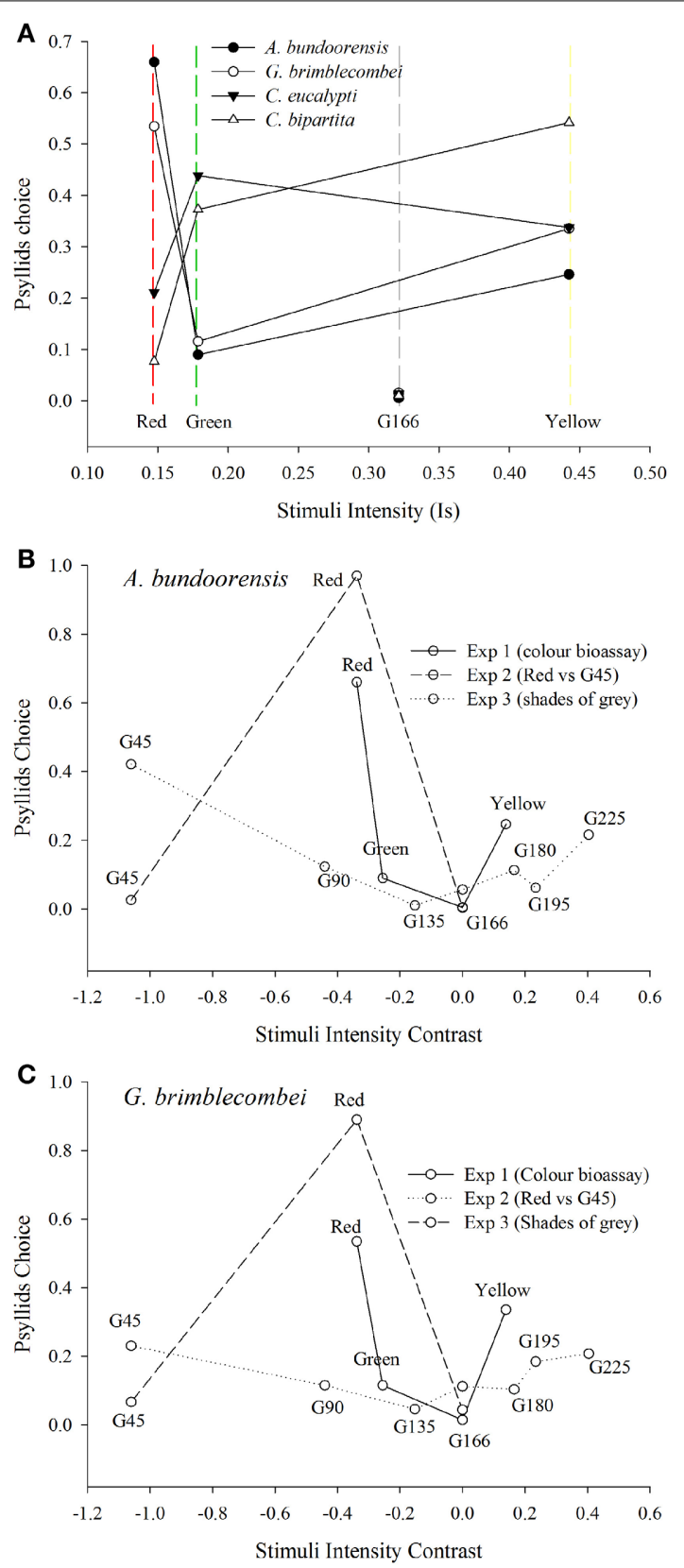

FIGURE 7 | Influence of stimuli intensity on psyllid choices (A) Shows the influence of stimuli intensities (see Equation 1) on the proportion of choosing psyllids. (B,C) represents psyllids choices according to the intensity contrast of the stimuli (see Equation 2) against the background used in the different behavioral experiments.

1973; Kieckhefer et al., 1976) and curiously, according to season (Moericke, 1955a; Prokopy and Owens, 1983; Ramirez et al., 2008). Our results are consistent with field studies in which higher catches of psyllids were obtained using yellow and green sticky traps (Mensah and Madden, 1992; Brennan and Weinbaum, 2001; Al-Jabr and Cranshaw, 2007; Hall et al., 2010). The current findings also complement lab studies that have shown that olfactory responses to host plant volatiles are enhanced when experienced 

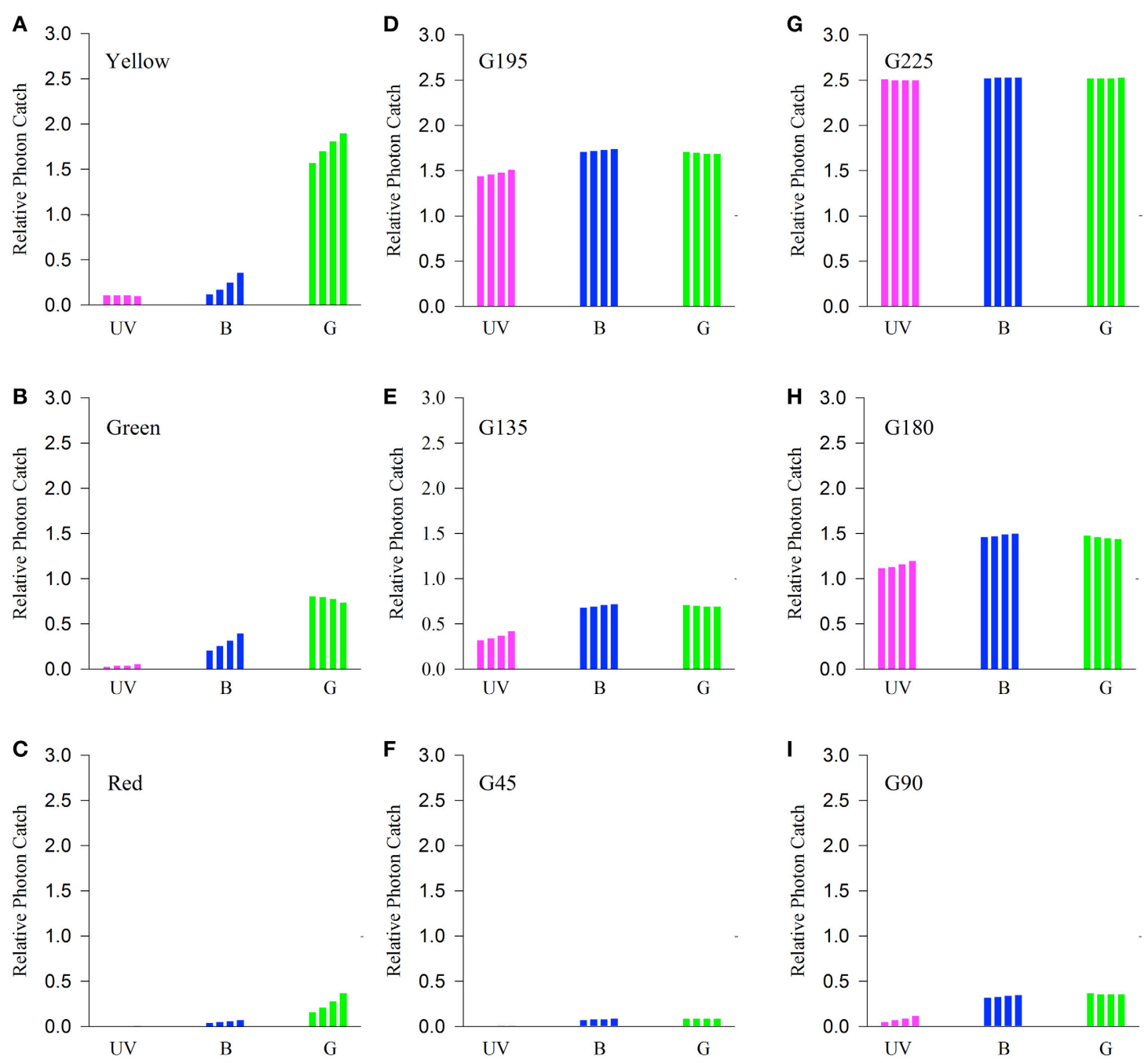

FIGURE 8 | Comparison of the quantity of light caught by putative psyllid photoreceptors. Bars represent relative photon catch of hypothetical photoreceptor sensitivities. Purple bars represent the quantity of light caught by the UV receptor (for $\alpha_{\max }=330,340,350$, and $360 \mathrm{~nm}$, successively); blue bars those of the blue receptor (for $\alpha_{\max }=430,440,450$, and $460 \mathrm{~nm}$ successively); and green bars those of the green receptor (for $\alpha_{\max }=530$, 540,550 , and $560 \mathrm{~nm}$ ) when exposed to color stimuli (A-C) and different shades of gray (D-I) under similar background conditions (G166). in conjunction with green or yellow stimuli (Wenninger et al., 2009; Patt et al., 2011).

By contrast, Anoeconeossa bundoorensis and Glycaspis brimblecombei strongly preferred "red" stimuli. "Yellow" was the second most chosen stimulus while "green" was only chosen occasionally. These observations contrast markedly with those of $C$. eucalypti and C. bipartita and more importantly with the literature pertaining to herbivorous insects. Since psyllid vision has received so little attention, it is currently impossible to estimate the incidence of attraction to long wavelength (red) stimuli among different species of psyllids, let alone more broadly within Hemiptera. High catches of the spruce aphid on red sticky traps is, to our knowledge, the only example of attraction to red within Sternorrhyncha (Straw et al., 2011). The preference of A. bundoorensis and G. brimblecombei for "red" forces us to consider that psyllid responses to color may not be limited to the usual yellow-green attraction observed in aphids.
The other question arising from our findings is how red is perceived by psyllids. Although most insects are known to have inherited the ancestral UV-blue-green set of photoreceptors (Chittka, 1996), their visual systems evolved different mechanisms to tune their spectral sensitivities to the cues most important to them. Thus, some insects, via the evolution of specific long wavelength photoreceptors and/or screening pigments, are able to perceive "red" as a true color. This is the case in numerous nectar-feeding lepidopterans and is not uncommon in other insect orders such as Odonata, Coleoptera and Hymenoptera. In most instances, the presence of "red" receptors is phylogenetically isolated and appears to be a consequence of convergent evolution (Briscoe and Chittka, 2001). Alternatively, "red" is perceived in the absence of specific red receptors via intensity-dependent stimulation of green photoreceptors. In the latter mechanism, called achromatic vision, "red" is perceived as a contrast or a level of brightness of the stimulus against its background. Achromatic 
insect vision has been shown to be involved in the detection of objects at long distance or under low light conditions. For instance, honeybees have been shown to rely alternately on chromatic and achromatic vision according to the visual angle of stimuli (Giurfa et al., 1997; Reisenman and Giurfa, 2008). Likewise, achromatic vision allows bees to detect red flowers although their conspicuousness is highly dependent on the background composition (Chittka and Waser, 1997). Some ant species have been shown to accurately discriminate between different color stimuli despite the apparent presence of a single photoreceptor type (Aksoy and Camlitepe, 2012). These examples demonstrate that attraction to a specific stimulus "color" may not be mediated by a color perception.

Given the current knowledge of hemipteran visual systems, psyllids have been presumed to be insensitive to long (red) wavelengths. However, our results show that, in the presence of a red and a dark gray (G45) stimulus of very low reflectance, two of the species of psyllids tested prefer "red" (Figure 5). This demonstrates that psyllids are somehow sensitive to long wavelengths, and such sensitivity promotes very clear preferences. Applying the extant wisdom, psyllids should not be able to discriminate between these two "dark" objects. One explanation for how insects might perceive long wavelength "red" radiation is via an achromatic mechanism as has been recently described in the rice leafhopper (Wakakuwa et al., 2014). This study revealed that under sufficiently high illumination conditions, leafhoppers could detect and orient toward long wavelengths stimuli when presented in a Y-maze apparatus. Electroretinograms and histological studies were conducted to prove that those responses were elicited in the absence of a specific long wavelength receptor, and that perception in the near infrared derived from the tail sensitivity of green receptors.

The possible role of a similar mechanism in psyllids was addressed in Experiment 3 by exposing psyllids to a variety of achromatic stimuli. Slight preferences for the darkest and brightest targets over the background indicate that psyllids used achromatic vision to locate the different gray stimuli. However, psyllids did not exhibit strong preference for any specific achromatic stimulus, in contrast to the very clear choices made in the presence of color stimuli. Calculations of intensity contrasts show that the dark gray (G45) offers a much greater contrast compared to the red stimulus (Figure 7A). Consequently, if contrast was the main factor influencing psyllid choice, dark gray (G45) would have been preferred over red. Likewise, reflectance calculations of the different stimuli reveal that the contrast of the "red" stimulus relative to the gray background is intermediate between that of G90 and G135 (Figures 7B,C), but neither of these targets was preferred. Hence, our results suggest that contrast of the stimuli against the background alone does not suffice for psyllids to prefer a specific stimulus. However, to appropriately address whether red can be perceived independently from intensity, responses of psyllids in the simultaneous presence of a red and various shade of grays need to be investigated.

Relative photon catches by putative UV-blue-green photoreceptors presented in Figure $\mathbf{8}$ show that, for all different sensitivity maxima tested, "red" stimulus associated stimulation varies only for the green photoreceptor. The intensity of stimulation of the green receptor would fluctuate between that of G45 (for $\lambda_{\max }=530 \mathrm{~nm}$ ) and that of G90 $\left(\lambda_{\max }=560 \mathrm{~nm}\right)$. Consequently, under the assumptions of the UV-blue-green model, and attraction to red mediated by the achromatic pathway, psyllids would not be able to discriminate between red and G45 (Experiment 2) and would prefer either G45 or G90 (Experiment 3). Our modeling of potential achromatic mechanisms did not find strong support for an achromatic explanation. However, considering the paucity of physiological data in Sternorrhyncha for which spectral sensitivity of only three species is known to date (Mellor et al., 1997; Kirchner et al., 2005; Döring et al., 2011), the assumptions of the modeling of putative photoreceptors incite us to remain cautious. Whilst our current findings may be explicable by a trichromatic visual system consistent with the principles outlined in Wakakuwa et al. (2014), our results do suggest that it would be of value for future research to explore the possibility of a red-sensitive receptor in psyllid species using either electrophysiological or DNA-sequencing techniques.

Since the reflectance of leaves differs most noticeably in the green region of the spectrum and beyond $(>500 \mathrm{~nm})$, the addition of a red receptor to UV-blue-green receptors greatly increases the potential to detect different foliar hues (Lythgoe, 1979). For instance, red receptors in sawflies (Peitsch et al., 1992) and swallowtail butterflies (Kelber, 1999; Kelber et al., 2003; Kelber, 2006) have been shown to allow color-based discrimination of leaves of different age. Importantly, this capacity permits such insects to exhibit oviposition preferences that are based on leaf age. The existence of a red receptor in an individual species within a given taxon, e.g., in the oligolectic bee Callonychium petuniae (Wittmann et al., 1990), demonstrates that its occurrence can be sporadic and reflective of the relative influence of specific ecological interactions and such instances may explain why we observe statistically different behavioral differences between closely related psyllid species.

In summary, our results demonstrate that psyllids are sensitive and attracted to long wavelengths. Since our modeling and psyllid responses in the presence of achromatic stimuli do not allow us to exclude an intensity-independent attraction to long wavelengths, the mechanism mediating attraction to "red" remains to be resolved.

The ecological motives for "red" attraction are potentially significant. Red coloration in leaves is ontogenetically related, generally as an adaptive response to abiotic stressors (nutrient deficiency, drought, cold, photoinhibition and all of the aforementioned acting in conjunction with herbivory); it is produced by the synthesis of foliar anthocyanins. Since anthocyanins share the same biosynthetic pathway (i.e., phenyl propanoid pathway) as defensive compounds such as phenolics, their presence often coincides with chemically well defended leaves of low palatability (Lev-Yadun and Gould, 2009). The co-evolution theory proposes that red colors in autumnal reddening leaves evolved for aposematic ends to reduce herbivore loads (Hamilton and Brown, 2001; Archetti and Brown, 2004). But other theories posit the physiological benefits conferred by anthocyanins in reducing photo-oxidative stress during nutrient recovery from senescing leaves and the protection of photosynthetically active 
(young) leaves from excess light (Close et al., 2001; Schaefer and Wilkinson, 2004; Schaefer and Rolshausen, 2007). For deciduous plants, "red" advertises the imminence of leaf abscission. Consequently, the general consensus is that there is little imperative for herbivorous insect to be attracted to red leaves and typically anthocyanin-rich senescing leaves are not utilized by sucking insects (Kennedy et al., 1961; Chittka and Döring, 2007).

Although it has attracted much less attention, "red" coloration is also common in young, expanding leaves of many evergreen trees (Chalker-Scott, 2002; Karageorgou and Manetas, 2006; Manetas, 2006; Hughes, 2011) including those in the genus Eucalyptus (Sharma and Crowden, 1974; Thomas and Barber, 1974; Specht and Brouwer, 1975). Since variations in pigment concentrations are often associated with changes in leaf physiology, they should provide cues to psyllids and other insects reliant on visual location and assessment of hosts. Although examples are scarce, some studies have shown how insects can exploit visual cues to locate host leaves (Prokopy et al., 1983; Reeves, 2011). There is somewhat more evidence concerning how foliar pigments attract herbivores to leaves of a specific physiological state (Kennedy et al., 1961; Vaishampayan et al., 1975b; Prokopy and Owens, 1983; Shoonhoven et al., 2005). Hence, the discrimination of host from non-host plants based on visual cues is most likely to be the exception rather than the rule and probably depends importantly on the diversity and the architecture of the surrounding vegetation. However, in the context of small sucking insects with limited dispersal capacities, plant pigments could certainly act as cues by which to locate and orient toward of a preferred leaf type or age within a single host. Interestingly, the two red attracted psyllids are specialist-feeders on young foliage of the same host (Eucalyptus camaldulensis), which usually has red young and recently expanded leaves (see Figure 9). However, similar red foliage is not expressed by the hosts of the greenyellow attracted psyllids. Consequently, there already appears to be anecdotal evidence of tuning of psyllid visual responses mediated by their respective host's foliar colors. Thus, we believe that attraction to red could confer an advantage to psyllids searching for young leaves because it is not associated with leaf abscission. However, whether "red" host leaves elicit similarly strong attraction in natural conditions as artificial "red" color in our bioassay remains to be tested. Visual contrast dictated by color stimuli and the background upon which those are applied has been shown to influence aphid' attraction to "green" stimuli (Döring et al., 2004; Döring, 2014). Future studies should attempt to measure psyllid responses to more realistic stimuli under natural background conditions.

Following alighting on a plant, aphid host range is ultimately determined by gustatory cues which determine whether alates settle or resume their search for a host (Powell et al., 2006). Recent work has shown that nutrient availability and quality may also influence psyllid establishment on host leaves (Taylor, 1997; Steinbauer, 2013) suggesting a direct parallel with processes by which some aphids select yellow autumnal leaves with high concentrations of mobilized nitrogen (Holopainen and Peltonen, 2002; Chittka and Döring, 2007; Döring and Chittka, 2007). The associations between foliar reflectance spectra, the ontogeny of host eucalypt leaves and their nutritional quality are ongoing

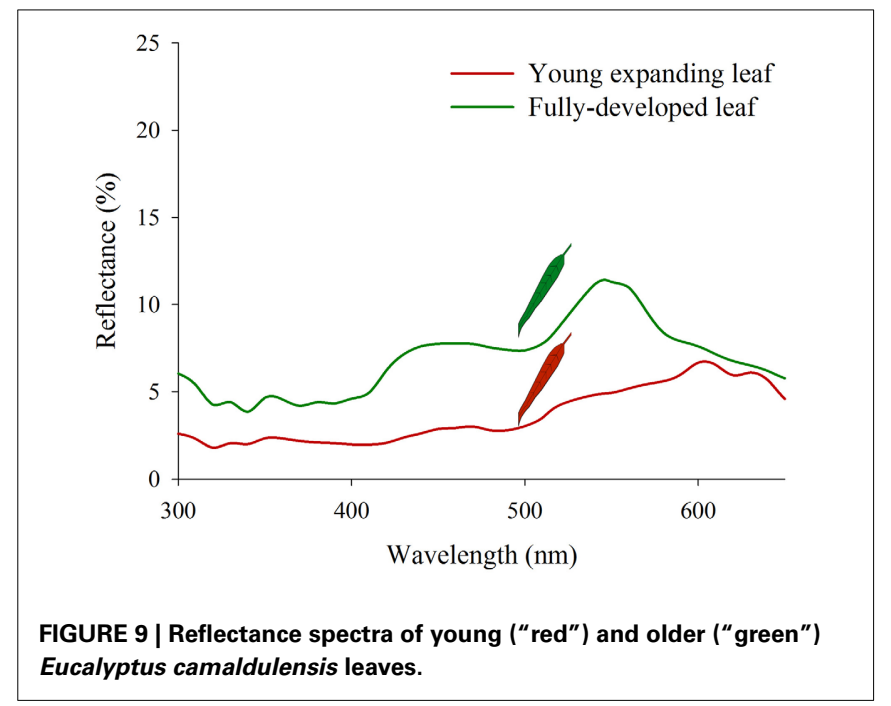

avenues of research by our group. Future papers of ours will address visually mediated host specificity in psyllids and whether foliar pigments provide information on plant physiology vital to their success.

\section{AUTHOR CONTRIBUTIONS}

Kevin Farnier, Adrian G. Dyer and Martin J. Steinbauer contributed to the experimental design. Experimental work and data analysis were performed by Kevin Farnier. Modeling work was done by Kevin Farnier with contribution from Adrian G. Dyer. Kevin Farnier wrote the paper which was revised by Martin J. Steinbauer and Adrian G. Dyer at early and final stages of the redaction.

\section{ACKNOWLEDGMENTS}

We thank Susan Hoebee and Trevor Edwards for use of their spectrophotometer, Angie Haslem and Simon Watson for statistical advice; Derek Wrede and Kaspar Delhey for assistance with bioassays. We are grateful to Almut Kelber, Eric Warrant and Richard Peters for comments on previous versions of the manuscript. The research was funded by an Australian Research Council (ARC) Future Fellowship [FT100100199] to Martin J. Steinbauer with associated Australian Postgraduate Award (APA) scholarship with top-up from La Trobe University to Kevin Farnier and an ARC Queen Elizabeth II (QEII) Research Fellowship [DP0878968] to Adrian G. Dyer.

\section{REFERENCES}

A'brook, J. (1973). Observations on different methods of aphid trapping. Ann. Appl. Biol. 74, 263-277. doi: 10.1111/j.1744-7348.1973.tb07747.x

Aksoy, V., and Camlitepe, Y. (2012). Behavioural analysis of chromatic and achromatic vision in the ant Formica cunicularia (Hymenoptera: Formicidae). Vision Res. 67, 28-36. doi: 10.1016/j.visres.2012.06.013

Al-Jabr, A. M., and Cranshaw, W. S. (2007). Trapping tomato psyllid, Bactehcera cockerelli (Sulc) (Hemiptera: Psyllidae), in greenhouses. Southwest. Entomol. 32, 25-30. doi: 10.3958/0147-1724-32.1.25

Archetti, M., and Brown, S. P. (2004). The coevolution theory of autumn colours. Proc. R. Soc. Lond. B Biol. 271, 1219-1224. doi: 10.1098/rspb.2004.2728

Bernays, E. A. (1998). Evolution of feeding behavior in insect herbivores. Bioscience 48, 35-44. doi: $10.2307 / 1313226$ 
Bleeker, P. M., Diergaarde, P. J., Ament, K., Guerra, J., Weidner, M., Schütz, S., et al. (2009). The role of specific tomato volatiles in tomato-whitefly interaction. Plant Physiol. 151, 925-935. doi: 10.1104/pp.109.142661

Brennan, E. B., and Weinbaum, S. A. (2001). Psyllid responses to colored sticky traps and the colors of juvenile and adult leaves of the heteroblastic host plant Eucalyptus globulus. Environ. Entomol. 30, 365-370. doi: 10.1603/0046-225X30.2.365

Briscoe, A. D., and Chittka, L. (2001). The evolution of color vision in insects. Annu. Rev. Entomol. 46, 471-510. doi: 10.1146/annurev.ento.46.1.471

Carver, M., Gross, G., and Woodward, T. (1991). Hemiptera (Bugs, Leafhoppers, Cicadas, Aphids, Scale Insects etc.). The Insects of Australia, Vol. 1. Melbourne, VIC: University Press.

Chalker-Scott, L. (2002). Do anthocyanins function as osmoregulators in leaf tissues? Adv. Bot. Res. 37, 103-127. doi: 10.1016/S0065-2296(02)37046-0

Chittka, L. (1996). Does bee color vision predate the evolution of flower color? Naturwissenschaften 83, 136-138. doi: 10.1007/BF01142181

Chittka, L., and Döring, T. F. (2007). Are autumn foliage colors red signals to aphids? PLoS Biol. 5:e187. doi: 10.1371/journal.pbio.0050187

Chittka, L., and Waser, N. M. (1997). Why red flowers are not invisible to bees. Isr. J. Plant Sci. 45, 169-183. doi: 10.1080/07929978.1997.10676682

Close, D. C., Davies, N. W., and Beadle, C. L. (2001). Temporal variation of tannins (galloylglucoses), flavonols and anthocyanins in leaves of Eucalyptus nitens seedlings: implications for light attenuation and antioxidant activities. Funct. Plant Biol. 28, 269-278. doi: 10.1071/PP00112

Coombe, P. E. (1982). Visual behaviour of the greenhouse whitefly, Trialeurodes vaporariorum. Physiol. Entomol. 7, 243-251. doi: 10.1111/j.1365-3032.1982.tb00297.x

Daumer, K. (1956). Reizmetrische Untersuchung des Farbensehens der Bienen. Zeitschrift für Vergleichende Physiologie 38, 413-478.

Döring, T. F. (2014). How aphids find their host plants, and how they don't. Ann. Appl. Biol. 165, 3-26. doi: 10.1111/aab.12142

Döring, T. F., and Chittka, L. (2007). Visual ecology of aphids-a critical review on the role of colours in host finding. Arthropod Plant Interact. 1, 3-16. doi: 10.1007/s11829-006-9000-1

Döring, T. F., Kirchner, S. M., Skorupski, P., and Hardie, J. (2011). Spectral sensitivity of the green photoreceptor of winged pea aphids. Physiol. Entomol. 36, 392-396. doi: 10.1111/j.1365-3032.2011.00805.x

Döring, T., Kirchner, S., Kühne, S., and Saucke, H. (2004). Response of alate aphids to green targets on coloured backgrounds. Entomol. Exp. Appl. 113, 53-61. doi: 10.1111/j.0013-8703.2004.00208.x

Dyer, A. G. (2006). Bumblebees directly perceive variations in the spectral quality of illumination. J. Comp. Physiol. A 192, 333-338. doi: 10.1007/s00359-0050088-z

Giurfa, M., Vorobyev, M., Brandt, R., Posner, B., and Menzel, R. (1997). Discrimination of coloured stimuli by honeybees: alternative use of achromatic and chromatic signals. J. Comp. Physiol. A 180, 235-243. doi: $10.1007 / \mathrm{s} 003590050044$

Grimaldi, D. (2005). Evolution of the Insects. Melbourne, VIC: Cambridge University Press.

Gross, J., and Mekonen, N. (2005). Plant odours influence the host finding behaviour of apple psyllids (Cacopsylla picta; C. melanoneura). IOBC Wprs Bull. 28, 351-355.

Gullan, P. J., and Cranston, P. S. (2009). The Insects: An Outline of Entomology. Oxford, UK: John Wiley \& Sons.

Hall, D. G., Sétamou, M., and Mizell, R. F. (2010). A comparison of sticky traps for monitoring Asian citrus psyllid (Diaphorina citri Kuwayama). Crop Prot. 29, 1341-1346. doi: 10.1016/j.cropro.2010.06.003

Hamilton, W. D., and Brown, S. P. (2001). Autumn tree colours as a handicap signal. Proc. R. Soc. Lond. B Biol. 268, 1489-1493. doi: 10.1098/rspb.2001.1672

Hardie, J. (1989). Spectral specificity for targeted flight in the black bean aphid, Aphis fabae. J. Insect. Physiol. 35, 619-626. doi: 10.1016/0022-1910(89) 90124-8

Hodkinson, I. D. (1974). The biology of the Psylloidea (Homoptera): a review. Bull. Entomol. Res. 64, 325-338. doi: 10.1017/S0007485300031217

Hodkinson, I. D. (2009). Life cycle variation and adaptation in jumping plant lice (Insecta: Hemiptera: Psylloidea): a global synthesis. J. Nat. Hist. 43, 65-179. doi: 10.1080/00222930802354167

Hollis, D. (2004). Australian Psylloidea Jumping Plantlice and Lerp Insects. Canberra: Australian Biological Ressources Study (ABRS).
Holopainen, J. K., and Peltonen, P. (2002). Bright autumn colours of deciduous trees attract aphids: nutrient retranslocation hypothesis. Oikos 99, 184-188. doi: 10.1034/j.1600-0706.2002.990119.x

Hughes, N. M. (2011). Winter leaf reddening in 'evergreen' species. New Phytol. 190, 573-581. doi: 10.1111/j.1469-8137.2011.03662.x

Isaacs, R., Willis, M. A., and Byrne, D. N. (1999). Modulation of whitefly takeoff and flight orientation by wind speed and visual cues. Physiol. Entomol. 24, 311-318. doi: 10.1046/j.1365-3032.1999.00144.x

Karageorgou, P., and Manetas, Y. (2006). The importance of being red when young: anthocyanins and the protection of young leaves of Quercus coccifera from insect herbivory and excess light. Tree Physiol. 26, 613-621. doi: 10.1093/treephys/26.5.613

Kelber, A. (1999). Ovipositing butterflies use a red receptor to see green. J. Exp. Biol. 202, 2619-2630.

Kelber, A. (2006). Invertebrate Colour Vision. Invertebrate Vision. Cambridge, MA: University Press, 250-290.

Kelber, A., Vorobyev, M., and Osorio, D. (2003). Animal colour visionbehavioural tests and physiological concepts. Biol. Rev. 78, 81-118. doi: $10.1017 /$ S1464793102005985

Kennedy, J. S., Booth, C. O., and Kershaw, W. J. S. (1961). Host finding by aphids in the field. Ann. Appl. Biol. 49, 1-21. doi: 10.1111/j.1744-7348.1961. tb03587.x

Kennedy, J., and Stroyan, H. (1959). Biology of aphids. Annu. Rev. Entomol. 4, 139-160. doi: 10.1146/annurev.en.04.010159.001035

Kennedy, J. S., and Thomas, A. A. G. (1974). Behaviour of some low-flying aphids in wind. Ann. Appl. Biol. 76, 143-159. doi: 10.1111/j.1744-7348.1974.tb07968.x

Kieckhefer, R., Dickmann, D., and Miller, E. (1976). Color responses of cereal aphids. Ann. Entomol. Soc. Am. 69, 721-724.

Kirchner, S. M., Döring, T. F., and Saucke, H. (2005). Evidence for trichromacy in the green peach aphid, Myzus persicae (Sulz.) (Hemiptera: Aphididae). J. Insect Physiol. 51, 1255-1260. doi: 10.1016/j.jinsphys.2005. 07.002

Koshitaka, H., Arikawa, K., and Kinoshita, M. (2011). Intensity contrast as a crucial cue for butterfly landing. J. Comp. Physiol. A 197, 1105-1112. doi: 10.1007/s00359-011-0671-4

Lev-Yadun, S., and Gould, K. S. (2009). "Role of anthocyanins in plant defence," in Anthocyanins, eds K. S. Gould, K. M. Davies, and C. Winefield (New York, NY: Springer), 22-28.

Lythgoe, J. N. (1979). The Ecology of Vision. Oxford: Clarendon Press.

Manetas, Y. (2006). Why some leaves are anthocyanic and why most anthocyanic leaves are red? Flora-Morphol. Distrib. Funct. Ecol. Plants 201, 163-177. doi: 10.1016/j.flora.2005.06.010

Mayer, C., Vilcinskas, A., and Gross, J. (2008). Pathogen-induced release of plant allomone manipulates vector insect behavior. J. Chem. Ecol. 34, 1518-1522. doi: 10.1007/s10886-008-9564-6

Mellor, H. E., and Anderson, M. (1995). Antennal sensilla of whiteflies: Trialeurodes vaporariorum (Westwood), the glasshouse whitefly, and Aleyrodes proletella (Linnaeus), the cabbage whitefly, (Homoptera: Aleyrodidae). Part 2: Ultrastructure. Int. J. Insect Morphol. Embryol. 24, 145-160. doi: 10.1016/00207322(95)93340-I

Mellor, H. E., Bellingham, J., and Anderson, M. (1997). Spectral efficiency of the glasshouse whitefly Trialeurodes vaporariorum and Encarsia formosa its hymenopteran parasitoid. Entomol. Exp. Appl. 83, 11-20. doi: 10.1046/j.15707458.1997.00152.x

Mensah, R. K., and Madden, J. L. (1992). Field studies on color preferences of Ctenarytaina thysanaura in Tasmanian boronia farms. Entomol. Exp. Appl. 64, 111-115. doi: 10.1111/j.1570-7458.1992.tb01600.x

Menzel, R. (1979). "Spectral sensitivity and color vision in invertebrates," in Comparative Physiology and Evolution of Vision in Invertebrates, ed H. Autrum (Berlin; Heidelberg: Springer), 503-580.

Moericke, V. (1950). Über das Farbsehen der Pfirsichblattlaus (Myzodes persicae Sulz.). Zeitschrift für Tierpsychologie 7, 265-274. doi: 10.1111/j.14390310.1950.tb02199.x

Moericke, V. (1955a). Über das Verhalten phytophager Insekten während des Befallsflugs unter dem Einfluß von weißen Flächen. Zeitschrift für Pflanzenkrankheiten 62, 588-593.

Moericke, V. (1955b). Über die Lebensgewohnheiten der geflügelten Blattläuse (Aphidina) unter besonderer Berücksichtigung des Verhaltens beim Landen 1. Zeitschrift für angewandte Entomologie 37, 29-91. 
Moericke, V. (1969). Host plant specific colour behaviour by Hyalopterus pruni (Aphididae). Entomol. Exp. Appl. 12, 524-534. doi: 10.1111/j.15707458.1969.tb02550.x

Patt, J. M., Meikle, W. G., Mafra-Neto, A., Setamou, M., Mangan, R., Yang, C., et al. (2011). Multimodal cues drive host-plant assessment in Asian citrus psyllid (Diaphorina citri). Environ. Entomol. 40, 1494-1502. doi: 10.1603/EN11149

Patt, J. M., and Sétamou, M. (2010). Responses of the Asian citrus psyllid to volatiles emitted by the flushing shoots of its rutaceous host plants. Environ. Entomol. 39, 618-624. doi: 10.1603/EN09216

Peitsch, D., Fietz, A., Hertel, H., Souza, J., Ventura, D. F., and Menzel, R. (1992). The spectral input systems of hymenopteran insects and their receptor-based colour vision. J. Comp. Physiol. A 170, 23-40. doi: 10.1007/BF00190398

Pickett, J., Wadhams, L., Woodcock, C., and Hardie, J. (1992). The chemical ecology of aphids. Annu. Rev. Entomol. 37, 67-90. doi: 10.1146/annurev.en.37.010192.000435

Pickett, J. A., and Glinwood, R. T. (2007). "Chemical ecology," in Aphids as Crop Pests, eds H. F. Van Emden and R. Harrington (London: CAB International), 235-259.

Powell, G., Tosh, C. R., and Hardie, J. (2006). Host plant selection by aphids: behavioral, evolutionary, and applied perspectives. Annu. Rev. Entomol. 51, 309-330. doi: 10.1146/annurev.ento.51.110104.151107

Prokopy, R. J., Collier, R. H., and Finch, S. (1983). Leaf color used by cabbage root flies to distinguish among host plants. Science 221, 190-192. doi: $10.1126 /$ science. 221.4606 .190

Prokopy, R. J., and Owens, E. D. (1983). Visual detection of plants by herbivorous insects. Annu. Rev. Entomol. 28, 337-364. doi: 10.1146/annurev.en.28.010183.002005

Quinn, G. P., and Keough, M. J. (2002). Experimental Design and Data Analysis for Biologists. Melbourne, VIC: Cambridge University Press.

Ramirez, C., Lavandero, B., and Archetti, M. (2008). Coevolution and the adaptive value of autumn tree colours: colour preference and growth rates of a southern beech aphid. J. Evol. Biol. 21, 49-56. doi: 10.1111/j.1420-9101.2007.01469.x

Reeves, J. L. (2011). Vision should not be overlooked as an important sensory modality for finding host plants. Environ. Entomol. 40, 855-863. doi: $10.1603 / \mathrm{EN} 10212$

Reisenman, C. E., and Giurfa, M. (2008). Chromatic and achromatic stimulus discrimination of long wavelength (red) visual stimuli by the honeybee Apis mellifera. Arthropod-Plant Interact. 2, 137-146. doi: 10.1007/s11829-008-9041-8

Schaefer, H. M., and Rolshausen, G. (2007). Aphids do not attend to leaf colour as visual signal, but to the handicap of reproductive investment. Biol. Lett. 3, 1-4. doi: 10.1098/rsbl.2006.0548

Schaefer, H. M., and Wilkinson, D. M. (2004). Red leaves, insects and coevolution: a red herring? Trends Ecol. Evol. 19, 616-618. doi: 10.1016/j.tree.2004.09.009

Schoonhoven, L., Jermy, T., and Van Loon, J. (eds.). (1998). "Host-plant selection: how to find a host plant," in Insect-Plant Biology (London: Chapman \& Hall), $121-153$.

Sharma, P., and Crowden, R. (1974). Anthocyanins in some Eucalyptus species. Aust. J. Bot. 22, 623-627. doi: 10.1071/BT9740623

Shoonhoven, L. M., Van Loon, J. J. A., and Dicke, M. (2005). Insect-Plant Biology. New York, NY: Oxford University Press Inc.

Soroker, V., Talebaev, S., Harari, A. R., and Wesley, S. D. (2004). The role of chemical cues in host and mate location in the pear psylla Cacopsylla bidens (Homoptera: Psyllidae). J. Insect. Behav. 17, 613-626. doi: 10.1023/B:JOIR.0000042544.35561.1c

Specht, R., and Brouwer, Y. M. (1975). Seasonal shoot growth of Eucalyptus spp. in the Brisbane area of Queensland (with notes on shoot growth and litter fall in other areas of Australia). Aust. J. Bot. 23, 459-474. doi: 10.1071/BT9750459

Stavenga, D., Smits, R., and Hoenders, B. (1993). Simple exponential functions describing the absorbance bands of visual pigment spectra. Vision Res. 33, 1011-1017. doi: 10.1016/0042-6989(93)90237-Q

Steinbauer, M. J. (2013). Shoot feeding as a nutrient acquisition strategy in freeliving Psylloids. PLoS ONE 8:e77990. doi: 10.1371/journal.pone.0077990
Straw, N. A., Williams, D. T., and Green, G. (2011). Influence of sticky trap color and height above ground on capture of alate Elatobium abietinum (Hemiptera: Aphididae) in Sitka spruce plantations. Environ. Entomol. 40, 120-125. doi: 10.1603/EN09344

Taylor, G. S. (1997). "Effect of plant compounds on the population dynamics of the Lerp insect, Cardiaspina albitextura Taylor (Psylloidea: Spondyliaspididae) on eucalypts," in Ecology and Evolution of Plant-Feeding Insects in Natural and ManMade Environments, ed A. Raman (Leiden: International Scientific Publications and Backhuys Publishers), 37-57.

Thomas, D., and Barber, H. (1974). Studies on leaf characteristics of a cline of Eucalyptus urnigera from Mount Wellington, Tasmania. I. Water repellency and the freezing of leaves. Aust. J. Bot. 22, 501-512. doi: 10.1071/BT97 40501

Vaishampayan, S. M., Kogan, M., Waldbauer, G. P., and Woolley, J. T. (1975a). Spectral specific responses in the visual behavior of the greenhouse whitefly, Trialeurodes vaporariorum (Homoptera: Aleyrodidae). Entomol. Exp. Appl. 18, 344-356. doi: 10.1111/j.1570-7458.1975.tb00407.x

Vaishampayan, S. M., Waldbauer, G. P., and Kogan, M. (1975b). Visual and olfactory responses in orientation to plants by the greenhouse whitefly, Trialeurodes vaporariorum (Homoptera: Aeyrodidae). Entomol. Exp. Appl. 18, 412-422. doi: 10.1111/j.1570-7458.1975.tb00418.x

Valterovà, I., Nehlin, G., and Borg-Karlson, A.-K. (1997). Host plant chemistry and preferences in egg-laying Trioza apicalis (Homoptera, Psylloidea). Biochem. Syst. Ecol. 25, 477-491. doi: 10.1016/S0305-1978(97)00028-8

Visser, J. (1986). Host odor perception in phytophagous insects. Annu. Rev. Entomol. 31, 121-144. doi: 10.1146/annurev.en.31.010186.001005

Visser, J., Piron, P., and Hardie, J. (1996). The aphids' peripheral perception of plant volatiles. Entomol. Exp. Appl. 80, 35-38. doi: 10.1111/j.15707458.1996.tb00880.x

von Frisch, K. (1914). Der Farbensinn und Formensinn der Biene. Zool. Jahrb. Abt. Allg. Zool. Physiol. 35, 1-182.

Von Helversen, O. (1972). Zur spektralen Unterschiedsempfindlichkeit der Honigbiene. J. Comp. Physiol. 80, 439-472. doi: 10.1007/BF00696438

Wakakuwa, M., Stewart, F., Matsumoto, Y., Matsunaga, S., and Arikawa, K. (2014). Physiological basis of phototaxis to near-infrared light in Nephotettix cincticeps. J. Comp. Physiol. A 200, 527-536. doi: 10.1007/s00359-014-0892-4

Wenninger, E. J., Stelinski, L. L., and Hall, D. G. (2009). Roles of olfactory cues, visual cues, and mating status in orientation of Diaphorina citri Kuwayama (Hemiptera: Psyllidae) to four different host plants. Environ. Entomol. 38, 225-234. doi: 10.1603/022.038.0128

Wittmann, D., Radtke, R., Cure, J., and Schifino-Wittmann, M. (1990). Coevolved reproductive strategies in the oligolectic bee Callonychium petuniae (Apoidea, Andrenidae) and three purple flowered Petunia species (Solanaceae) in southern Brazil. J. Zool. Syst. Evol. Res. 28, 157-165. doi: 10.1111/j.14390469.1990.tb00373.x

Conflict of Interest Statement: The authors declare that the research was conducted in the absence of any commercial or financial relationships that could be construed as a potential conflict of interest.

Received: 02 July 2014; accepted: 04 October 2014; published online: 22 October 2014. Citation: Farnier K, Dyer AG and Steinbauer MJ (2014) Related but not alike: not all Hemiptera are attracted to yellow. Front. Ecol. Evol. 2:67. doi: 10.3389/fevo. 2014.00067

This article was submitted to Behavioral and Evolutionary Ecology, a section of the journal Frontiers in Ecology and Evolution.

Copyright () 2014 Farnier, Dyer and Steinbauer. This is an open-access article distributed under the terms of the Creative Commons Attribution License (CC BY). The use, distribution or reproduction in other forums is permitted, provided the original author(s) or licensor are credited and that the original publication in this journal is cited, in accordance with accepted academic practice. No use, distribution or reproduction is permitted which does not comply with these terms. 